\title{
Sustainability and Determinate of Farmers' Mitigation Strategies to Greenhouse Gases Emission: a case in Rice Agric-Food System of Nigeria
}

\author{
Esiobu, Nnaemaka Success ${ }^{1 *} \quad$ Onubuogu, Chinedu Gilbert ${ }^{1} \quad$ Njoku, Sylvarlene Munachim ${ }^{2}$ \\ Nwachukwu, Blessing Chidinma ${ }^{3}$ \\ 1.Department of Agricultural Economics, Extension and Rural Development, Imo State University, Owerri, \\ Nigeria \\ 2.Department of Nutrition and Dietetics, Imo State University, Owerri, Nigeria \\ 3.Food Security and Safety Niche, Faculty of Natural and Agricultural Sciences, North-West University, South \\ Africa
}

\begin{abstract}
Sustainable production refers to the production that meets the needs of the present, without compromising the ability of future generations to meet their own needs. At global level and mainly across Nigeria, rice fields are considered as one of the most important sources of atmospheric concentration of two greenhouse gases mainly anthropogenic methane $\left(\mathrm{CH}_{4}\right)$ and nitrous oxide $\left(\mathrm{N}_{2} \mathrm{O}\right)$ emissions. These Greenhouse Gases (GHGs) are produced under anaerobic conditions, and its production has negative environmental and health implication. Additionally, the growing demand for rice across Nigeria exceeds supply, resulting in a rice deficit. To overcome this challenge, rice production should be increased, with so much regard to less GHGs emission. Moving forward, understanding the determinate of farmers' mitigation strategies to GHGs will definitely enhance effort made for farmers to continue to mitigate easily over-time. Incidentally, an empirical study on the present discourse is relatively scanty, isolated, and devoid of in-depth and quantitative analyses. These create a gap in research and make it extremely difficult if not impossible for the government/interest group to know the method they can adopt in helping farmers mitigate the negative impact of GHGs emission in rice production. It was against this backdrop that this study was systematically undertaken.
\end{abstract}

Keywords: Rice, Greenhouse Gases (GHGs), Mitigation Strategies, Sustainability and Multinomial Model, Nigeria

DOI: $10.7176 / \mathrm{JESD} / 11-15-06$

Publication date:August $31^{\text {st }} 2020$

\section{INTRODUCTION}

Sustainable production refers to the production that meets the needs of the present, without compromising the ability of future generations to meet their own needs [16]. For an agricultural production to be sustainable, it must produce food with regard not only to the environment (to ensure production can continue on an indefinite basis) but also to generating sufficient production to meet the demand and producing an adequate return for farmers to support their standard of living those yet unborn. Therefore, Rice (Oryza spp) which is the second-largest most consumed cereal (after wheat) shapes the lives of millions of households globally [10]. More than half the worlds' population depends on rice for about $80 \%$ of its food calorie requirements [2]. It has become a staple food in Nigeria such that every household; both the rich and the poor consume a great quantity. A combination of various factors seems to have triggered the structural increase in rice consumption over the years with consumption broadening across all socio-economic classes, including the poor [23]. Rising demand could be as a result of increasing population growth and income level coupled with the ease of its preparation and storage. Currently, due to the present government objective on diversification of the economy, rice is grown in almost 36 States in Nigeria including Federal Capital Territory (FCT) under diverse production systems and agro-climatic conditions. Additionally, the growing demand for rice across sub-Saharan Africa and particularly in Nigeria exceeds supply, resulting in a rice deficit. In the same way, Nigeria is the continent's leading consumer of rice, one of the largest producers of rice in Africa and simultaneously one of the largest rice importers in the world. Incidentally, rice field is a significant anthropogenic source of methane $\left(\mathrm{CH}_{4}\right)$ and nitrous oxide $\left(\mathrm{N}_{2} \mathrm{O}\right)$, two important greenhouse gases (GHGs). Methane, which accounts for $20-30 \%$ of the global warming effect, is second only to carbon dioxide $\left(\mathrm{CO}_{2}\right)$ as the most significant GHGs[12]. Methane from rice fields represents about $10 \%$ of non- $\mathrm{CO}_{2}$ emissions from agriculture [18] and about $89 \%$ of the global warming potential (GWP) from rice [25]. The current understanding of the determinate of farmers' mitigation strategies to GHGs emission in rice agric-food system in Nigeria has not much been empirically documented. Additionally, to the best of our knowledge, no study has systematically modeled farmers' mitigation strategies to GHGs emission using Multinomial logit regression. The multinomial logit model is an extension of the binary logit model for modeling categorical dependent variables with more than two categories. The dependent variable is assumed to follow a multinomial distribution, a 
generalization of the binomial distribution. This create a gap in knowledge and makes it absolutely difficult if not impossible for researchers, the government and policymakers to know the method they can adopt in assisting the farmers increase their production, their standard of living, and livelihood in a cleaner environment. Despite the importance attached to understanding rice production under a cleaner environment, it is somewhat surprising that little or nothing is known about farmers socio-economic characteristic; farmers' mitigation strategies to GHGs emissions; how farmers socio-economic characteristic influences their mitigation strategies and the barrier they encounter in mitigating GHGs in the area. Empirical evidence remains largely scanty, isolated and devoid of indepth and quantitative analysis. It was against these backdrops that it became increasingly pertinent that the study was systematically and logically undertaken.

\section{METHODOLOGY}

The study was carried out in Imo State, Nigeria. Imo State is located in the eastern zone of Nigeria. The State lies between Latitudes $4^{\circ} 45^{\prime} \mathrm{N}$ and $7^{\circ} 15^{\prime} \mathrm{N}$ and Longitude $6^{\circ} 50^{\prime} \mathrm{E}$ and $7^{\circ} 25^{\prime} \mathrm{E}$ [21]. It is bounded on the east by Abia State, on the west by the River Niger and Delta State; and on the north by Anambra State, while Rivers State lies to the south. Imo State covers an area of about $5,067.20 \mathrm{~km}^{2}$, with a population of $3,934,899[\mathbf{1 7}, \mathbf{2 0}]$ and population density of about $725 \mathrm{~km}^{2}$ [11]. The State has three Agricultural zones namely Orlu, Owerri, and Okigwe Agricultural Zones. The State has an average annual temperature of $28^{\circ} \mathrm{C}$, an average annual relative humidity of $80 \%$, average annual rainfall of 1800 to $2500 \mathrm{~mm}$ and an altitude of about $100 \mathrm{~m}$ above sea level [11]. The State experiences two major seasons: dry and rainy seasons. The State has fertile and well-drained soil suitable for rice farming and a good proportion of the population are essentially farmers. A multistage and purposive random method was used in the selection of respondents. Purposive sampling method was used to select respondents who are predominantly rice farmers. The sample size comprised one-hundred and twenty (120) rice farms. A well structured questionnaire was the main tool for data collection. Data collected were analyzed using descriptive statistical tools and a multinomial logit model. The model was given below as follows:

If $p_{i j}$ is the probability of $y_{i}$ falling in category $j, j=1,2, \ldots, J$, then

$\ln \left(\frac{p_{i j}}{p_{i J}}\right)=\alpha_{j}+\beta_{j} X_{i}, j=1,2, \ldots, J-1$

leading to

$p_{i j}=\frac{e^{\alpha_{j}+\beta_{j} X_{i}}}{1+\sum_{k=1}^{J-1} e^{\alpha_{k}+\beta_{k} X_{i}}}, \quad j=1, \ldots, J-1$

and

$$
p_{i J}=\frac{1}{1+\sum_{k=1}^{J-1} e^{\alpha_{k}+\beta_{k} X_{i}}}
$$

Where $\mathrm{P}=$ Response Probability $(J=0,1,2,3,---7)$

$\mathrm{Y}=$ Mitigation Category; $J=1,2, \ldots, 8$;

$1=$ Alternative Wetting and Drying of rice (AWD),

$2=$ System of rice intensification $(\mathrm{SRI})$,

$3=$ Changing tillage operations (CTO)

4= Nitrogen Fertilizer Management (NFM)

$5=$ Residue Management $(\mathrm{RM})$

$6=$ Aerobic Rice Varieties (ARC)

$7=$ No Mitigation strategies

The explanatory variables are as follows;

$\mathrm{Y}=\mathrm{f}\left(\mathrm{X}_{1}, \mathrm{X}_{2}, \mathrm{X}_{3}, \mathrm{X}_{4}, \mathrm{X}_{5}, \mathrm{X}_{6}, \mathrm{X}_{7}, \mathrm{X}_{8}, \mathrm{X}_{9}, \mathrm{X}_{10}, \mathrm{X}_{11}\right)+e i \ldots \ldots$

$\mathrm{X}_{1}=$ Age (years)

$\mathrm{X}_{2}=$ Sex $($ Male $=1$, Female $=0)$

$\mathrm{X}_{3}=$ Educational level (years)

$\mathrm{X}_{4}=$ Farming experience (years).

$\mathrm{X}_{5}=$ Household size (Number of persons)

$\mathrm{X}_{6}=$ Farm income $(\mathrm{N})$ 
$\mathrm{X}_{7}=$ Farm size (Hectare)

$\mathrm{X}_{8}=$ Extension Contact $($ Contact $=1$, No-contact $=0)$

$\mathrm{X}_{9}=$ Access to farm credit (access $=1$, No-access $=0$ )

$\mathrm{X}_{10}=$ Access to GHGs emission Information $($ access $=1$, No-access $=0$ )

$\mathrm{e}_{\mathrm{i}}=$ error term

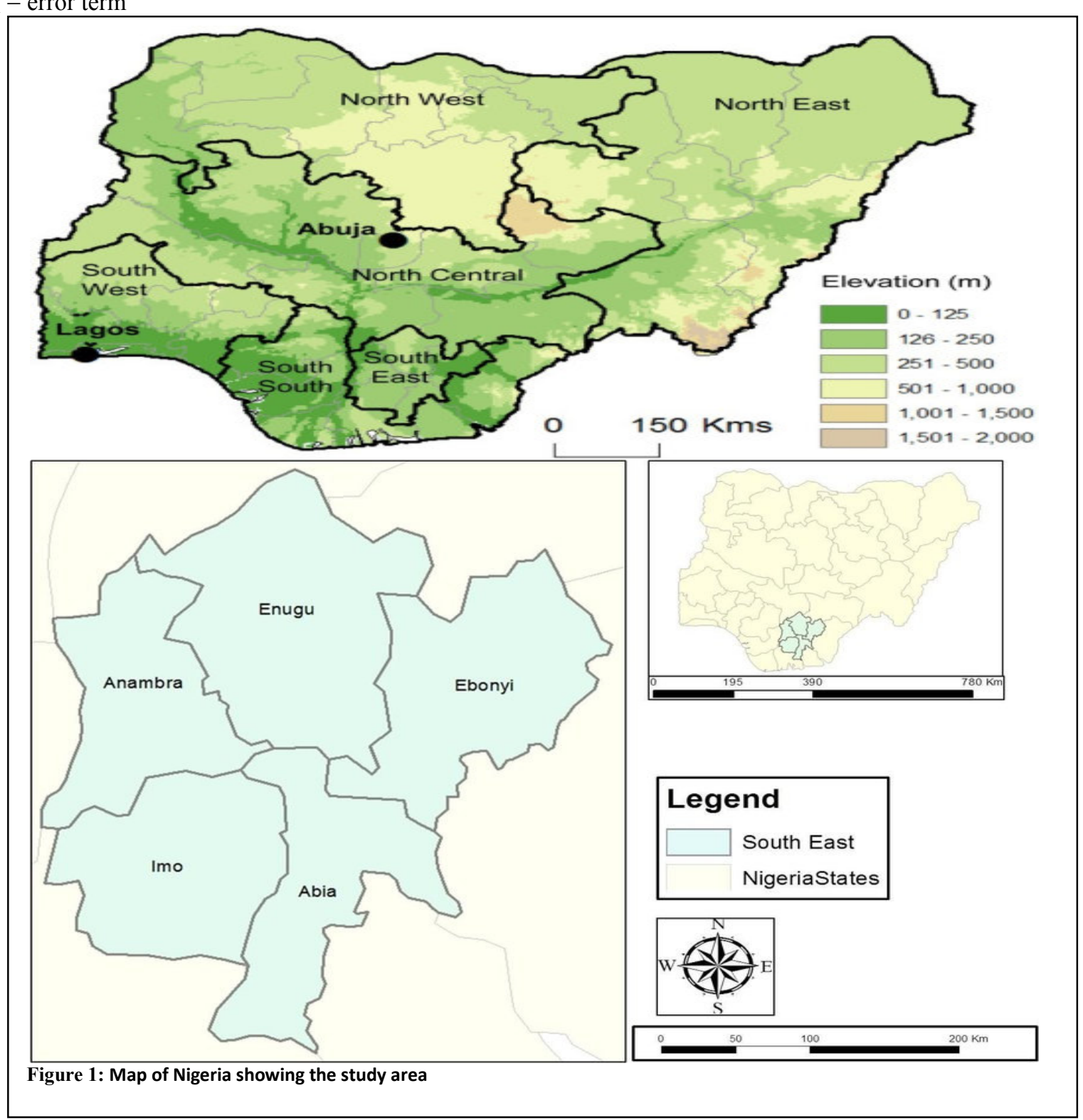

\section{RESULTS AND DISCUSSION}

\section{Socio-economic Characteristics of Rice Farmers}

Table 1 revealed that majority (59.17\%) fell within the age range of 41-50 years. The mean age was 45.00 years. This shows that farmers in the area are vibrant, young and still within the active age. Rice farming is so strenuous. The implication is that younger farmers are more likely to practice more and modern mitigation strategies in GHGs emission faster than the older ones. Young farmers are more likely to know about new mitigation strategies to avert GHGs emission with the willingness to bear risk. Table 1 also reveals that majority (75.85\%) of the farmers were males. The finding implies that both sex are involved in rice farming but female are more in number in the area. This is true as male farmers has been found to be more relatively efficient that women [7]. 
Table 1: Socio-economic Characteristics of Rice Farmers

\begin{tabular}{|c|c|c|c|}
\hline Age (years) & Frequency & Percentage $(\%)$ & Mean (X) \\
\hline $21-30$ & 5 & 4.17 & \\
\hline $31-40$ & 11 & 9.16 & \\
\hline $41-50$ & 71 & 59.17 & \\
\hline $51-60$ & 30 & 25.00 & \\
\hline $61-70$ & 3 & 2.50 & \\
\hline Total & 120 & 100.0 & 45.00years \\
\hline Male & 91 & 75.83 & \\
\hline Female & 29 & 24.16 & \\
\hline Total & 120 & 100.0 & \\
\hline Educational Level (Years) & Frequency & Percentage $(\%)$ & \\
\hline No formal education & 6 & 5.00 & \\
\hline Primary & 41 & 34.17 & \\
\hline Secondary & 64 & 53.33 & \\
\hline Tertiary & 9 & 7.50 & \\
\hline Total & 120 & 100.0 & $\begin{array}{l}12 \text { years equivalent to } \\
\text { secondary education }\end{array}$ \\
\hline Marital Status & Frequency & Percentage $(\%)$ & \\
\hline Single & 8 & 6.67 & \\
\hline Married & 101 & 84.17 & \\
\hline Divorced & 4 & 3.33 & \\
\hline Widowed & 7 & 5.83 & \\
\hline Total & 120 & $\mathbf{1 0 0 . 0}$ & \\
\hline Farming Experience (Years) & Frequency & Percentage $(\%)$ & \\
\hline $1-5$ & 38 & 63.33 & \\
\hline $6-10$ & 9 & 15.00 & \\
\hline $11-15$ & 5 & 8.33 & \\
\hline $16-20$ & 8 & 13.33 & \\
\hline $21-25$ & 9 & 7.50 & \\
\hline Total & 120 & 100.0 & 23 years \\
\hline Household Size (Number of Persons) & Frequency & Percentage $(\%)$ & \\
\hline $1-2$ & 2 & 1.67 & \\
\hline $3-4$ & 5 & 4.17 & \\
\hline $5-6$ & 11 & 9.17 & \\
\hline $7-8$ & 29 & 24.17 & \\
\hline $9-10$ & 51 & 42.50 & \\
\hline $11-12$ & 13 & 10.83 & \\
\hline $13-14$ & 9 & 6.67 & \\
\hline Total & 120 & 100.0 & 9.00 persons \\
\hline Extension Contact & Frequency & Percentage $(\%)$ & \\
\hline Contact (yes) & 31 & 25.83 & \\
\hline Non-contact (no) & 89 & 74.17 & \\
\hline Total & 120 & $\mathbf{1 0 0 . 0}$ & \\
\hline Access to Credit & Frequency & Percentage (\%) & \\
\hline Access & 46 & 76.67 & \\
\hline No access & 14 & 23.33 & \\
\hline Total & 120 & 100.0 & \\
\hline Access to GHGs Information & Frequency & Percentage (\%) & \\
\hline Access & 107 & 89.17 & \\
\hline No-access & 13 & 10.83 & \\
\hline Total & 120 & 100.0 & \\
\hline
\end{tabular}




\begin{tabular}{|l|l|l|l|}
\hline Farm Size(Ha) & Frequency & Percentage (\%) & \\
\hline $0.1-0.99$ & 27 & 22.50 & \\
\hline $1.0-2.50$ & 83 & 69.17 & \\
\hline $2.60-3.00$ & 10 & 8.33 & $2.28 \mathrm{ha}$ \\
\hline Total & $\mathbf{1 2 0}$ & $\mathbf{1 0 0}$ & \\
\hline Annual Farm Income (N) & Frequency & Percentage (\%) & \\
\hline $100,001-200,000$ & 21 & 17.50 & \\
\hline $200,001-300,000$ & 25 & 20.83 & \\
\hline $300,001-400,000$ & 65 & 54.17 & \\
\hline $400,001-500,000$ & 9 & 7.50 & \\
\hline Total & $\mathbf{1 2 0}$ & $\mathbf{1 0 0 . 0}$ & $\mathbf{N 4 0 0 , 7 9 0 . 0 0}$ \\
\hline & & & \\
\hline
\end{tabular}

\section{Source: Field Survey Data, 2020}

Entries in Table 1 also show that greater proportion (53.33\%) had secondary school education. The main education level is 12 years which is equivalent to secondary school education. The finding implies that approximately $95.00 \%$ of the farmers had formal education which is expected to increase their level of understanding on the effect of GHGs emissions in rice farms and various mitigation strategies to practice in thwarting the negative effect. Result in Table 1 shows that majority $(84.17 \%)$ were married. The finding implies that rice farming is an enterprise of married individual who are expected to be responsible according to societal standard. Married farmers have likelihood of adapting to climate change easily than their unmarried counterpart since they have access to labour. Result of farming experience is shown in Table 1 and it shows that about $27.50 \%$ of the farmers had a farming experience ranging from 11-15 years. The mean year of experience in farming was 15.00 years. This shows that the farmers were quite experienced in rice farming and may have been adapting to several mitigation strategies to GHGs emissions in the area. It is expected that farmers with more experience are more likely to accept innovations and new mitigation strategies to GHGs emissions than inexperienced farmer. The number of years of farming helps to cushion the effects of GHGs emissions, since GHGs emissions is yearly recurring decimal during rice farming. Result in Table 1 also show that majority $(74.17 \%)$ of the farmers had no contact with extension agents. The implication is that majority of the farmers may not have the opportunity of learning new mitigation options in GHGs emissions and consequently exposing their rice farming to incidence of $\mathrm{CH}_{4}$ and $\mathrm{N}_{2} \mathrm{O}$ impact in the area. It becomes clear that there is need for the government to strengthen the Agricultural Development programme (ADP) to facilitate timely extension contacts with farmers in the area. The provision of information and guidance to farmers in any farming season would increase in mitigation to GHGs emissions and improvement in their faming enterprise in a cleaner environment. Entries in Table 1 revealed that about $42.50 \%$ had a household size ranging from 9-10. The mean household size was found to be 9.00 persons. The result shows that farmers had large households. The implication is that they could draw farm labour from their households for the practice of various mitigation strategies to GHGs emissions in rice farming. Table 1 shows that majority (89.17\%) of the farmers have access to GHGs emission information. This implies that farmers in the study area have access to GHGs emissions information which enhances their easy mitigation to multiple choices in GHGs emissions. It is expected that farmers who have access to GHGs emissions information will be more aware of effect of GHGs emissions and practice better mitigation measures that farmers with no access to information. Table 1 revealed that majority (69.17\%) of the farmers had farm size of between 2.00-2.50 hectares. The finding implies that the farmers in the area are mainly smallholder farmers operating on less than or equal to 2.50 hectares of farmland. This could be as a result of land tenure system or increasing population prevalent in the area. Additionally, the small farm size is not even contiguous plot but rather small plots scattered in different areas of the community. It is expected that farmers with large farm size will practice more GHGs strategies than those with lesser farmland in the area. More so, larger farm size enhances the probability of household choosing multiple and better measures to GHGs emission than household with smaller farm size. Finally, Table 1 indicates that majority (54.14\%) had an average annual farm income of between $\mathrm{N} 300,001-\mathrm{N} 400,000$. The mean annual farm income was $\mathrm{N} 400,790.00$ while monthly farm income was estimated to be $\mathrm{N} 33,399.167$. The finding implies that the farmers have a relatively low farm income despite the larger household size which they recorded. The implication of the findings is that farmers may not have the much needed financial capacity to mitigate to GHGs emission. This is true as some mitigation strategies to GHGs emission are costly. Hence, farmers may have several GHGs emission strategies they want to practice but limited fund may continue to hinder them.

\section{FARMERS GHGs EMISSION MITIGATION STRATEGIES IN RICE FARMING}

Result in Figure 2 reveals farmers GHGs emission mitigation strategies in rice farming in the area. Similarly, it is very possible that the various mitigation strategies used by the rice farmers to reduce the negative impacts of GHGs emission in their farming activities could be profit driven rather than GHGs emission driven. In strengthening the 
above assertion, the study of [9] reported that the action of farmers in reducing the negative impact of climate change over time has basically been climate change driven, hence the study assumed that the rice farmers various mitigation measures is therefore GHGs emission driven. The result reveals that about $98.10 \%$ of the farmers identified Alternative Wetting and Drying of Rice (AWD) as one of their several mitigation strategies to climate change. AWD is basically a method of reducing $30.00 \%$ of water in rice farms to influences GHGs emission reduction by $48 \%$. The AWD process influences rice production, $\mathrm{CH} 4$, and $\mathrm{N}_{2} \mathrm{O}$ emissions from rice systems. The finding is supported by the study of [16] who found that Single or multiple drainages management during a rice growing season (e.g., AWD) reduces $\mathrm{CH}_{4}$ emissions by 48 to $93 \%$ compared to those observed under continuous flooding systems. Approximately, $92.00 \%$ identified System of Rice intensification (SRI). The SRI is a holistic approach for sustainable rice cultivation. It involved planting single seedling with more space between them rather than by the handful and bunched closely together. It also involves watering intermittently and allowing for a dry spells rather than using continuous flooding and use of organic input. The study of [6] confirmed similar finding as one of the strategies used by rice farmers in GHGs mitigation. Additionally, about $79.00 \%$ of the farmers practiced Changing Tillage Operations (CTO). The study of $[4,5]$ concluded that biomass incorporation under conventional tillage is the main cause of the higher $\mathrm{CH}_{4}$ emissions, implying that rice production systems where residue incorporation is excluded (no-till) may contribute to mitigation of GHGs emissions. Similarly, the finding agrees with the study of Ahmed et al., (2009) also reported significant reductions in $\mathrm{CH}_{4}$ emissions (21-60\%) from no-till compared to tilled fields. In the same vein, Nitrogen Fertilizer Management (NFM) was identified by $66.00 \%$ of the farmers. The application of nitrogen $(\mathrm{N})$ fertilizer to agricultural soils increases productivity and may also influence GHG emissions from rice systems. The finding of [15] found that $\mathrm{N}$ fertilizer-induced $\mathrm{N} 2 \mathrm{O}$ emissions were reported to be $0.21 \%$ under continuous flooding and $0.40 \%$ under alternate wetting and drying (AWD) rice production systems. In the same meta-analysis an effect of fertilizer type was reported, with N2O emissions shown to increase by $24 \%$ and $\mathrm{CH} 4$ emissions to decrease by $40 \%$ when urea was replaced by ammonium sulphate. Others (58.00\% and 35.00\%) identified Residue Management (RM) and Aerobic Rice Varieties (ARC) respectively. The incorporation of rice residues contributes toward long-term nutrient cycling but may, due to high $\mathrm{C} / \mathrm{N}$ ratios, cause short-term $\mathrm{N}$ immobilization and thus affect $\mathrm{N}$ availability for subsequent crops [15]. Meanwhile, Aerobic Rice Varieties (ARV) is a production system in which especially developed "aerobic rice" varieties are grown in well-drained, non-puddled, and non-saturated soils [24].

With a good management, the system aims for yields of at least 4-6 tons per hectare. Therefore, the finding became clear that farmers are noticing changes in rice field and have started practicing several strategies to thwart the negative effect of GHGs emission in their rice farming.

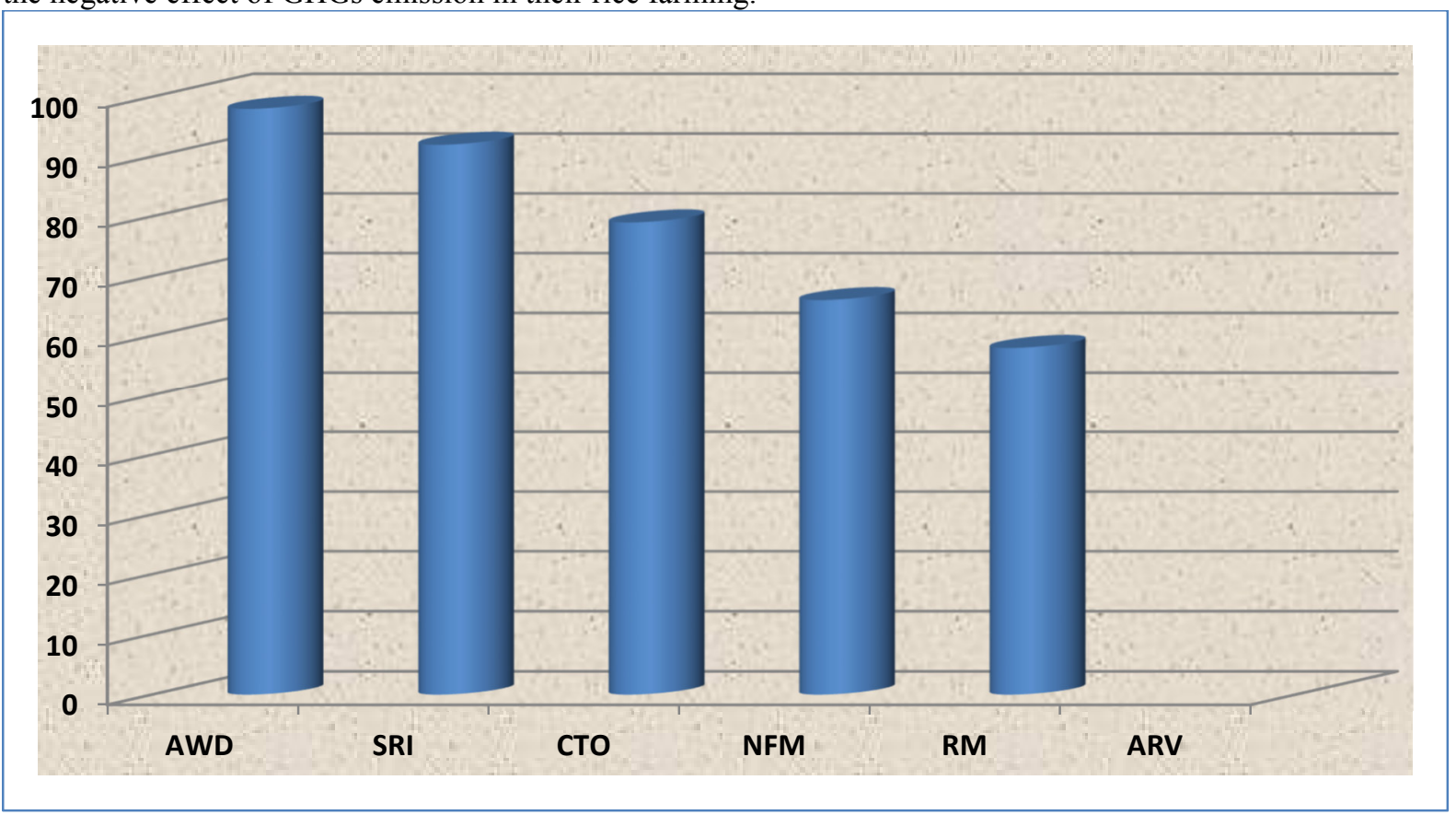

Figure 2: GHGs Emission Mitigation Strategies of Rice Farmers in the Study area

Keys: Alternative Wetting and Drying of Rice (AWD); System of Rice intensification (SRI); Changing Tillage Operations (CTO); Nitrogen Fertilizer Management (NFM); Residue Management (RM) and Aerobic Rice Varieties (ARV) 


\section{DETERMINANTS OF RICE FARMERS MITIGATION STRATEGIES TO GHGS EMISSION}

The Table 2 shows determinants of rice farmers' mitigation strategies to GHGs emission. The estimation of the multinomial logit model for this study was undertaken by normalizing one category, which is normally referred to as the "reference or base category". In this analysis, the last category (no mitigation Strategies) is the reference category. The model was run and tested for the validity of the independence of the irrelevant alternatives (IIA) assumption by using the Hausman test for IIA. The test accepted the null hypothesis of independence of the Mitigation Strategies to GHGs emission, suggesting that the multinomial logit specification is appropriate and a good fit to model farmers Mitigation Strategies to GHGs emission. Results reveals a likelihood ratio chi-square $(\chi 2)$ values of 0.9770 implying that $97.70 \%$ of variation in the model for the mitigation strategies was explained by the explanatory variables while the remaining $2.30 \%$ was accounted for due to stochastic error. The model was also statistically significant at $1 \%(\mathrm{P}<0.00001)$, suggesting that the models have strong explanatory power. This indicates that all the models had good fit to the model. The significance of this likelihood ratio statistics test indicates that rice farmers' socio-economic characteristics significantly influence the use of mitigation strategies for GHGs emission in the area. Consequently, the interpretation and discussion of the multinomial logit result indicates the following:

Age $\left(\mathbf{X}_{1}\right)$ : Age of the rice farmers significantly influences mitigation to GHGs emission. Age of the farmers was positive across the practice of Alternative Wetting and Drying of Rice (AWD); System of Rice intensification (SRI); Nitrogen Fertilizer Management (NFM); Residue Management (RM) and Aerobic Rice Varieties (ARV). This reason could be because the options have been practised for a long period of time and are well known by older farmers than their younger counterparts. On the other hand, age of the farmers had a negative influence on the probability of uptake of CTO. The result shows that a unit increase in the age of the farmers decreases the likelihood of taking up CTO by $0.21(2.10 \%)$. This could be because CTO may require more physical strength and energy to practice in rice farming of which older farmers may not have the capacity to do. The result is consistent with the findings of [9] who noted that the older farmers becomes the more risk averse and practice less strategies particularly those requiring more energy over time.

Sex $\left(\mathbf{X}_{2}\right)$ : The result indicated that female-headed households practiced efficiently and more mitigation strategies to GHGs emission than their male counterpart. On the other hand, male-headed households were more readily resilient to GHGs emission than their female counterparts by practicing SRI and CTO. The finding tallies with the study of [13] who asserted that female are more involved in rural agriculture. This is true as women use it to support their families nutritionally and income wise while the male households usually migrate to urban city in search of for non-agricultural job. Additionally, it is also expected that female will understand perceived effect of GHGs emission in rice farming and practice modern mitigation strategies than their male counterpart.

Educational level $\left(\mathbf{X}_{3}\right)$ : Education of the farmers was positive across all the mitigation strategies to GHGs emission. This result is line with the a priori expectation of the model. The finding is in line with the study of [8] who asserted that exposure to higher education of the farmer increases the probability of choosing different sustainable farming method. The probable reason could be due to the fact that educated farmers have more knowledge of GHGs Emission and are already aware of various techniques and management practices they could be employed to mitigate easily. Additionally, the study of [14] also confirmed the importance of education on choice of mitigation strategies to GHGs emission.

Farming experience $\left(\mathbf{X}_{4}\right)$ : Farming experience had a positive and significant relationship across all the mitigation strategies to GHGs Emission modeled. This implies that increase in years of experience increases the probability of uptake of AWD; SRI; CTO; NFM; RM and ARV. Highly experienced farmers are likely to have more information and knowledge on GHGs emission than their counterpart with limited years of experience. In addition, experience exposes farmers' to various GHGs emission strategies they could employed in the face of anticipated environmental situation. The findings support [26] who asserted that farmers' with more experience would be more efficient, have better knowledge of climatic conditions and market situation and are thus, expected to run a more efficient and profitable enterprise.

Household size $\left(\mathbf{X}_{5}\right)$ : Household size of farmers increased the likelihood of using CTO, RM, SRI practices by $0.001(1.00 \%)$. This indicates that household size increases the probability of uptake of these mitigation measures to climate change because such options require additional labour from the farmers which is usually provided by his/her household members. On the other hand, household size of farmers decreased the likelihood of practicing ARV and NFM by $0.0001(0.1 \%)$. This is because, as the hectare of farmland cultivated by each farmer reduces, the labour needed by such farmers also reduces. The finding tallies with the study of [23]who reported that large household size is associated with a higher labour endowment which would enable household to accomplish various agricultural tasks especially at the peak seasons and ensures ease adaptation to climate change. The finding is also supported by the result of [9] who opined that large household size has shown to provide cheap and available source of labour for farmers in adapting easily to climate change.

Farm Income $\left(\mathbf{X}_{\mathbf{6}}\right)$ : The income of farmers had a positive and significant influence on the likelihood of practicing all the mitigation measure identified. Higher income farmers are less risk averse and have more access to 
information, a lower discount rate, a longer-term planning horizon and wealthier than less-income farmers. Additionally, with more financial and other resources at their disposal, farmers are able to change their management practices in response to changing climatic, GHGs emissions and other factors and are better able to make use of all the available information they might have on changing conditions both climatic and other socioeconomic factors. The result shows that a unit increase in the income of the farmers increased the likelihood of adopting of practicing AWD; SRI; CTO; NFM; RM and ARV. The study of [16] reported that farmers with higher farm income will make better decision, use necessary productive inputs, and realize huge yield/output than their counterparts who have low farm income. Additionally, the study of [9] also reported that adaptation options to climate change area costly.

Farm size $\left(\mathbf{X}_{7}\right)$ : Farmers' land area cultivated was negatively related to mitigation strategies to GHGs emissions in the area. The negative relationship between farmers mitigation strategies to GHGs emissions and farm size is inconsistent with the study carried out by [19] but in line with [9] who reported that the probable reason could be due to the fact that adaptation/mitigation measures is plot-specific. It is expected that farmers with large farm size will practice more mitigation strategies to GHGs emissions than those with lesser farmland in the area. More so, larger farm size enhances the probability of household choosing multiple and better mitigation strategies to GHGs emissions than household with smaller farm size. This means that it is not the size of the farm but the specific characteristics of the farm that dictates the need for specific adaptation mitigation strategies to GHGs emissions in rice production

Extension contact $\left(\mathbf{X}_{\mathbf{8}}\right)$ : Extension contact had a positive and significant influence across all the mitigation strategies to GHGs emissions modelled. The finding shows that a unit increase in the number of extension visits to the farmers increased the likelihood of AWD by $0.006(0.6 \%)$, SRI by $0.013(1.3 \%)$, CTO by $0.054(5.4 \%)$, NFM by $0.08(8.00 \%)$, RM by $0.0051(5.1 \%)$ and ARV by $0.23(23.00 \%)$. Contact with extension agents which denotes access to information had positive effect across all adaption measures indicating that extension contact increases the likelihood of mitigating to GHGs emissions in rice farm easily. Access to extension services significantly increased the probability of taking up AWD; SRI; CTO; NFM; RM and ARV. Extension services provide an important source of information on GHGs emissions as well as agricultural production and management practices. Farmers who have significant extension contacts have better chances to be aware of changing climatic conditions and also of the various management practices that they can use to practices to changes in climatic conditions. The findings is in line with the study [22] argued that extension contact enhance farmers production and promote their knowledge on modern farming methods.

Access to farm credit $\left(\mathbf{X}_{\mathbf{9}}\right)$ : Result showed that farmers' access to credit significantly increased the probability of uptake of AWD; SRI; CTO; NFM; RM and ARV. Inadequate fund is one of the main constraints to adjustment to climate change [9]. Despite the various mitigation strategies farmers could be aware of and willing to practice, inadequate fund to purchase the necessary inputs and other associated equipment remains one of the significant barriers to mitigation strategies to GHGs emissions in rice production.

Access to GHGs emission information $\left(\mathbf{X}_{10}\right)$ : which depicts level of awareness of GHGs emissions significantly increased the probability of uptake of all the mitigation strategies identified. Farmers who have access to GHGs emissions and climate information are more aware of changes in climatic conditions and have higher chances of taking adaptive measures in response to observed changes. It is an important precondition for farmers to take up mitigation strategies. Information on climate variables like temperature amount, relative humidity, rainfall amount and sunshine duration has really helped farmers in the area on the time to plant a particular breed of rice. Farmers' access to information on GHGs emissions is likely to enhance their probability to perceive GHGs emissions and climate change, and hence practice of new technologies and take-up better mitigation techniques. 
Table 2: Estimated Multinomial Logit Model of the Determinants of Rice Farmers Mitigation Strategies to GHGs Emission

\begin{tabular}{|c|c|c|c|c|c|c|}
\hline $\begin{array}{l}\text { Explanatory } \\
\text { Variables }\end{array}$ & AWD & SRI & CTO & NFM & $\mathbf{R M}$ & ARV \\
\hline Age $\left(\mathrm{X}_{1}\right)$ & $\begin{array}{l}-1.0079 \mathrm{e}- \\
03 \\
(-3.11)^{* * *}\end{array}$ & $\begin{array}{l}0.00085 \\
(4.02)^{* * *}\end{array}$ & $\begin{array}{l}-0.021 \\
(-3.10)^{* * *}\end{array}$ & $\begin{array}{l}0.004 \\
(3.84) * *\end{array}$ & $\begin{array}{l}0.0093 \\
(3.38)^{* * *}\end{array}$ & $\begin{array}{l}-0.0098 \\
(-3.92)^{* * *}\end{array}$ \\
\hline $\operatorname{Sex}\left(X_{2}\right)$ & $\begin{array}{l}-0.00015 \\
(-0.11)\end{array}$ & $\begin{array}{l}0.0006 \\
(0.76) \\
\end{array}$ & $\begin{array}{l}0.234 \\
(1.17)^{*}\end{array}$ & $\begin{array}{l}-0.155 \\
(-0.12) \\
\end{array}$ & $\begin{array}{l}-0.23 \\
(-0.05)\end{array}$ & $\begin{array}{l}0.14 \\
(0.87)\end{array}$ \\
\hline Educational Level $\left(\mathrm{X}_{3}\right)$ & $\begin{array}{l}4.20 \mathrm{e}-06 \\
(1.08)^{*}\end{array}$ & $\begin{array}{l}0.00009 \\
(0.63)\end{array}$ & $\begin{array}{l}0.008 \\
(0.96)\end{array}$ & $\begin{array}{l}0.012 \\
(-0.68)\end{array}$ & $\begin{array}{l}-0.02 \\
(-1.64)^{*}\end{array}$ & $\begin{array}{c}-0.009 \\
(-0.91)\end{array}$ \\
\hline $\begin{array}{l}\text { Farming Experience } \\
\left(\mathrm{X}_{4}\right)\end{array}$ & $\begin{array}{l}-4.96 \mathrm{e}-06 \\
(-0.76)\end{array}$ & $\begin{array}{l}-0.00005 \\
(-0.51)\end{array}$ & $\begin{array}{l}0.011 \\
(1.35)^{*}\end{array}$ & $\begin{array}{l}0.0015 \\
(1.01)\end{array}$ & $\begin{array}{l}-0.011 \\
(-0.52)\end{array}$ & $\begin{array}{l}-0.007 \\
(-0.63)\end{array}$ \\
\hline Household size $\left(\mathrm{X}_{5}\right)$ & $\begin{array}{l}-0.000042 \\
(-0.25)\end{array}$ & $\begin{array}{l}0.0004 \\
(0.14)\end{array}$ & $\begin{array}{l}0.003 \\
(0.35)\end{array}$ & $\begin{array}{l}0.017 \\
(0.12)\end{array}$ & $\begin{array}{l}-0.009 \\
(-0.19)\end{array}$ & $\begin{array}{l}-0.001 \\
(-0.29)\end{array}$ \\
\hline Farm Income $\left(\mathrm{X}_{6}\right)$ & $\begin{array}{l}1.39 \mathrm{e}-08 \\
(2.16)^{* *}\end{array}$ & $\begin{array}{l}3.79 \mathrm{e}-09 \\
(1.94)^{*}\end{array}$ & $\begin{array}{l}7.54 \mathrm{e}-09 \\
(1.09)\end{array}$ & $\begin{array}{l}3.02 \mathrm{e}-06 \\
(1.63)^{*}\end{array}$ & $\begin{array}{l}2.66 \mathrm{e}-06 \\
(1.50)^{*}\end{array}$ & $\begin{array}{l}2.74 \mathrm{e}-06 \\
(0.69)\end{array}$ \\
\hline Farm size $\left(X_{7}\right)$ & $\begin{array}{l}-0.00046 \\
(-0.68)\end{array}$ & $\begin{array}{l}-0.0006 \\
(-1.46) \\
\end{array}$ & $\begin{array}{l}-0.07 \\
(-0.88)\end{array}$ & $\begin{array}{c}-0.112 \\
(-0.98) \\
\end{array}$ & $\begin{array}{l}-0.03 \\
(-0.59)\end{array}$ & $\begin{array}{l}-0.12 \\
(-1.45)\end{array}$ \\
\hline Extension Contact $\left(\mathrm{X}_{8}\right)$ & $\begin{array}{l}0.0051 \\
(3.21)^{* * *}\end{array}$ & $\begin{array}{l}0.006 \\
(5.04)^{* * *}\end{array}$ & $\begin{array}{l}0.013 \\
(4.85)^{* * *}\end{array}$ & $\begin{array}{l}0.054 \\
(5.10)^{* * *}\end{array}$ & $\begin{array}{l}0.08 \\
(4.69) * * *\end{array}$ & $\begin{array}{l}0.23 \\
(4.97) * * *\end{array}$ \\
\hline $\begin{array}{l}\text { Access to farm credit } \\
\left(\mathrm{X}_{9}\right)\end{array}$ & $\begin{array}{l}0.027 \\
(4.04)^{* * *}\end{array}$ & $\begin{array}{l}-0.00098 \\
(-1.63) \\
\end{array}$ & $\begin{array}{l}-0.134 \\
(-1.60) \\
\end{array}$ & $\begin{array}{l}0.161 \\
(1.84)^{*}\end{array}$ & $\begin{array}{l}0.11 \\
(0.95) \\
\end{array}$ & $\begin{array}{l}0.08 \\
(0.95) \\
\end{array}$ \\
\hline $\begin{array}{ll}\text { Access } & \text { to } \text { GHGs } \\
\text { emission } & \text { information/ } \\
\left(\mathrm{X}_{10}\right) & \end{array}$ & $\begin{array}{l}4.37 \mathrm{e}-06 \\
(0.37)\end{array}$ & $\begin{array}{l}0.179 \\
(5.01)^{* * *}\end{array}$ & $\begin{array}{c}-0.169 \\
(-0.13)\end{array}$ & $\begin{array}{l}-0.023 \\
(-0.25)\end{array}$ & $\begin{array}{l}0.04 \\
(0.54)\end{array}$ & $\begin{array}{l}-0.04 \\
(-0.21)\end{array}$ \\
\hline Pseudo $\mathrm{R}^{2}$ & \multicolumn{6}{|l|}{0.5919} \\
\hline Likelihood Chi square & \multicolumn{6}{|l|}{$97.70 * * *$} \\
\hline Sample Size (n) & \multicolumn{6}{|l|}{120} \\
\hline $\begin{array}{l}\text { Reference / Base } \\
\text { Category }\end{array}$ & \multicolumn{6}{|c|}{ No Mitigation Strategies } \\
\hline
\end{tabular}

Output of STATA; Values in parenthesis are Z-Values; ${ }^{* * *}$ Significant at $1 \%$ level, ${ }^{* *}$ Significant at $5 \%$ level, "Significant at 10\% level; Field Survey, 2020

Keys: Alternative Wetting and Drying of Rice (AWD); System of Rice intensification (SRI); Changing Tillage Operations (CTO); Nitrogen Fertilizer Management (NFM); Residue Management (RM) and Aerobic Rice Varieties (ARV)

\section{Rice Farmers' Barrier to mitigation of GHGs Emission}

The findings in Figure 3 shows rice farmers' barrier to mitigation of GHGs emission in the area. The finding reveals that about $98.30 \%$ of the farmers identified of inadequate information. This could be attributed to dearth in research on GHGs emission, mitigation strategies as well as lack of information on climatic variables which should always be dissemination by Nigerian Meteorological Agency (NiMET). This constraint left the farmers unable to get the much needed information on climate change and GHGs emission. In the present information age, inadequate information could pose serious challenges to the farmers' coping strategies as they may not be aware of recent developments regarding GHGs emission, mitigation strategies and the necessary re-adjustments needed. Poor information on mitigation strategies to GHGs emission in rice farming may result to food insecurity and unsustainable production overtime. About $94.75 \%$ identified inadequate fund. Inadequate fund left most of the rice farmers unable to get necessary resources in mitigating to GHGs emission in the area. This could be attributed to high cost of mitigation options. Inadequate fund hinders farmers from getting the necessary resources and technologies which assist to mitigate efficiently to GHGs emission. The result shares view with the study of [9] who argued that adaptation options are costly hence farmers need adequate fund to adapt. Going forward, poor extension contact, high cost of inputs, poor access to farm credit, limited availability of farmland were identified by $87.50 \%, 83.33 \%, 82.50 \%$ and $75.74 \%$ of the rice farmers respectively. High cost of farm inputs could also be attributed to inadequate fund. With limited fund, the acquisition of necessary facilities will be difficult. They may not only be costly, but may also appear scarce for poor farmers. In addition, the farmers may not also have the necessary facilities for current information like radio and television to obtain weather forecasts. Poor access of credit could be linked to lack of information or awareness of the presence of loan facilities, high collateral and location of banks in urban which is far from the rural areas where farmers live. Limited farmland could be attributed 
to of land tenure system or increasing population prevalent in the area. High population pressures force farmers to intensively farm over a small plot of land and make them unable to conserve from further damages by practices such as planting tress which competes agricultural land. It becomes clear that this constraint is responsible for poor production of rice and GHGs emission mitigation in the area. Curbing this barrier will be vital in promoting not just local mitigation strategies but global strategies of GHGs emission in the area and perhaps beyond.

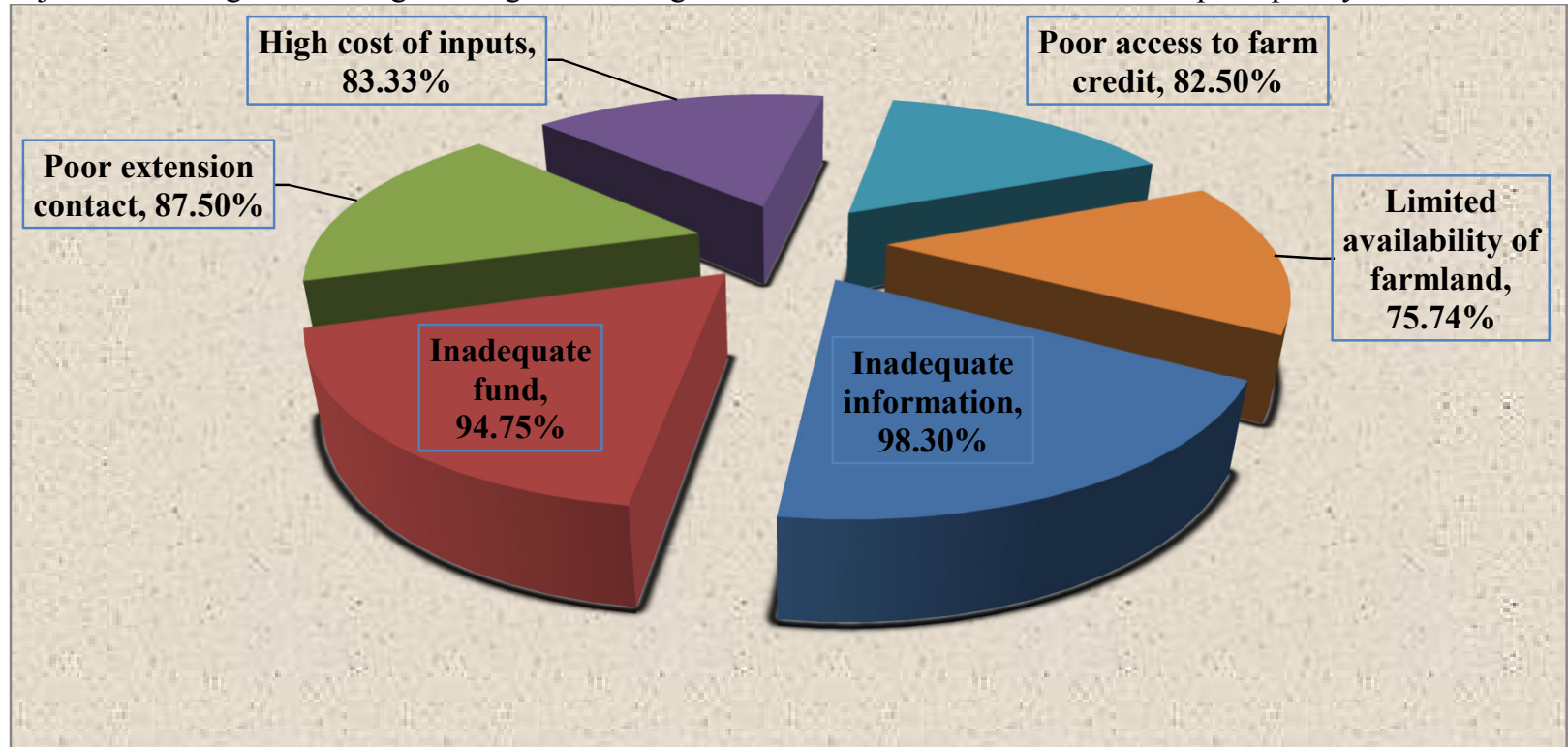

Figure 3: Rice Farmers' Barrier to Mitigation of GHGs Emission

\section{CONCLUSION AND RECOMMENDATION}

Conclusively, the study was logically guided by describing the socio-economic characteristics of the rice farmers; identifying and describing the mitigation strategies to GHGs used by rice farmers and constraints in mitigating GHGs in rice farming. A multistage and purposive random method was used in the selection of respondents. Purposive sampling method was used to select respondents who are predominantly rice farmers. The sample size comprised one-hundred and twenty (120) rice farms. A well-structured questionnaire was the main tool for data collection. Data collected were analyzed using descriptive statistical tools and a multinomial logit model. Result shows that the mean age was 45.00 years. Greater proportions $(75.83 \%)$ were male. Majority $(84.17 \%)$ were married with an average household size of 9 persons. The mean educational level and farming experiences were 12 years (equivalent to secondary school education) and 23.00 years respectively. Average farm size and annual farm income were 2.28 hectares and N400,790.00 (1027.67USD) respectively. Result confirmed the incidence of GHGs emission in rice farm the area. Interestingly, farmers are becoming increasingly aware and have started practising several mitigation strategies. The major GHGs mitigation strategies the farmers practice were alternative wetting and drying of rice [AWD] $(98.10 \%)$ and the system of rice intensification $[\mathrm{SRI}](92.00 \%)$ among various strategies they practiced simultaneously. Estimated multinomial logit model revealed that household size $\left(\mathrm{X}_{5}\right)$, farm size $\left(\mathrm{X}_{7}\right)$ and education $\left(\mathrm{X}_{9}\right)$ significantly influence their choice of GHGs mitigation strategies at $1 \%$ level of probability. Regrettably, farmers complained of inadequate fund (98.33\%). It was therefore recommended that farmers should form a stable cooperative to access fund, information and government support effectively. In the same way, the study confirmed the incidence of GHGs emission in rice farm the area. Interestingly, farmers are becoming increasingly aware and are noticing the GHGs emission. The farmers has started practicing several mitigation strategies to thwart the negative effect of GHGs emission while remaining sustainable. The major GHGs mitigation strategies of farmers practice were alternative wetting and drying of rice (98.10\%) and the system of rice intensification $(92.00 \%)$ among various strategies they practice simultaneously. The study also looked at the determinants of rice farmers use of various mitigation option to GHGs emission using a multinomial logit model. The model permits the analysis of decisions across dichotomous categories, allowing the determination of choice probabilities for different categories. Multinomial logit results confirmed that access to credit, extension services, farming experience, education, access to credit, access to climate change information and farm size were some of the significant determinants of farm-level mitigation options. The main barrier to the mitigation of GHGs emission were lack of information on appropriate mitigation option which could be attributed to dearth in research on GHGs emission as well as poor information dissemination on the part of extension agents in the study area. 


\section{RECOMMENDATIONS}

The following recommendations were made based on the major research observations and findings of the study.

i. Effective agricultural policies and programmes should focus on how to intensify awareness on GHGs emission in rice farm as well as its mitigation strategies. This should be done through strengthened agricultural extension delivery

ii. Since education and farmland was found to significantly increase mitigation, investment strategies should also focus on expansion of farmers' farmland and improvement of their education as this would affect their mitigation to GHGs emission positively.

iii. The government must also design policy in such a way that farmers should have access to affordable credit as well as subsidized agricultural inputs in order to increase their ability and flexibility to change production strategies in response to the forecasted climatic conditions.

iv. The government or interested organization should endeavor to build weather stations in all local government areas in Nigeria to reduce the incidence of poor climate record keeping and to provide midterm forecast of weather and other climatic variables.

v. Ultimately, incorporating local knowledge into GHGs emission concerns should not be done at the expense of modern/western scientific knowledge. Local knowledge should complement rather than compete with global modern practices in counteracting the negative impact of GHGs emission in the area and beyond.

\section{Appreciation}

Special thanks to the local rice farmers in the study area who provided the data for the study. Additionally, many thanks to our volunteer field enumerator who helped in visiting the sampled farmers in their remote rice farms for evidenced-based data collection. Thanks to all those involved in data entry, data cleaning, data coding and analysis. We can't thank you all enough.

\section{REFERENCES}

[1] Ahmad, S.; Li, C.; Dai, G.; Zhan, M.; Wang, J.; Pan, S.; Cao, C. (2009). Greenhouse gas emission from direct seeding paddy field under different rice tillage systems in central China. Soil Tillage Res. 106, 54-61.

[2] Akande, T (2020). An Overview Of The Nigerian Rice Economy; Agriculture and Rural Development Department The Nigerian Institute of Social and Economic Research (NISER); https://unep.ch/etb/etp/events/Agriculture/nigeria.pdf

[3] Ariyo, O.C , Ariyo, M.O, Okelola, O.E, Aasa, O.S, Awotide, O.G, Aaron, A.J, and Oni, O.B (2013). Assessment of the Role of Mass Media in the Dissemination of Agricultural Technologies among Farmers in Kaduna North Local Government Area of Kaduna State, Nigeria; Journal of Biology, Agriculture and Healthcare; Vol.3, No.6,

[4] Bayer, C.; Costa, F.S.; Pedroso, G.M.; Zschornack, T.; Camargo, E.S.; Lima, M.A.; Frigheto, R.T.S.; Gomes, J.; Marcolin, E.; Macedo, V.R.M. (2014). Yield-scaled greenhouse gas emissions from flood irrigated rice under long term conventional tillage and no-till systems in a Humid Subtropical climate. Field Crop Res, 162, 60-69.

[5] Bayer, C.; Zschornack, T.; Pedroso, G.M.; da Rosa, C.M.; Camargo, E.S.; Boeni, M.; Marcolin, E.; Cecilia dos Reis, C.E.S.; dos Santos, D.C. (2015). A seven-year study on the effects of fall soil tillage on yield-scaled greenhouse gas emission from flood irrigated rice in a humid subtropical climate. Soil Tillage Res, 145, 118125.

[6] Bharali, A, Baruah K.K, Gogoi N (2017). Potential option for mitigating methane emission from tropical paddy rice through selection of suitable rice varieties. Crop and Pasture Science 68:421-433.

[7] Esiobu, N. S (2018). Relative Efficiencies of Resource Use Among Cassava Farmers in Imo State, Nigeria; An M.Sc Thesis Submitted To The Department Of Agricultural Economics, Extension And Rural Development, Faculty Of Agriculture And Veterinary Medicine; Imo State University, Owerri, Nigeria

[8] Esiobu, N.S and Onubuogu G.C (2018). Determinant of Risk-Smart Options among Farming Households in Agricultural Risk Management in Imo State, Nigeria; (A Multinomial Logit Model Approach); Journal of Environment Protection and Sustainable Development , ;Vol.3, No.10, Pp; 20-39

[9] Esiobu, N.S, and Onubuogu G.C (2014).Trend, perceptions and adaptation options of Arable crop farmers to Climate change in Imo State Nigeria; A multinomial logit Approach; World Science Journal Vol. 5(9), Pp:. 12-24

[10] Food and Agricultural Organisation (FAO).(2020). The State of Food and Agriculture; 2010-2019. Rome: FAO; 2020.

[11] Imo State Agricultural Development Programme (Imo-ADP) (2018). Work Programme, Imo ADP, Owerri, Imo State, Nigeria

[12] Intergovernmental Panel on Climate Change (IPCC) (2019) Climate Change 2014: Mitigation of Climate 
Change. Contribution ofWorking Group III to the Fifth Assessment Report of the Intergovernmental Panel on Climate Change

[13] Kughur, P., Gyanden, O, Omaku, S and Isa M (2018). Assessment of Input Needs of Women Vegetable Farmers in Gwer-East Local Government Area of Benue State, Nigeria; Volume 2, 2018 DOI: 10.31058/j.as.2018.23013

[14] Kushal, K B (2018). Analysis of Greenhouse Gas (Methane and Nitrous Oxide) emission and global warming potential from rice fields: with reference to biological mitigation of climate change; Journal of Earth Sciences \& Environmental Studies 3(2)

[15] Linquist, B.A.; Adviento-Borbe, M.A.; Pittelkow, C.M.; van Kessel, C.; van Groenigen, K.J. Fertilizer (2012). Management practices and greenhouse gas emissions from rice systems: A quantitative review and analysis. Field Crops Res, 135, 10-21.

[16] Munonye, J.O and Esiobu, N.S (2017). Sustainability and Agribusiness Development in Nigeria; Journal of Sustainable Development; An International Peer-reviewed Journal Vol.27,Pp:40-44

[17] National Bureau of Statistics (NBS) (2007). National Bureau of Statistics Official Gazette (FGP 71/52007/2,500(OL24): Legal Notice on Publication of the Details of the Breakdown of the National and State Provisional Totals, 2006 Census. www.nigerianstat.gov.ng (accessed 28 February, 2016)

[18] Ngonidzashe, C, Laura A, Maria K, Sandra, L, Fernando C1, Manabu I, Ana M, Deissy M , Eduardo G, Santiago J, Carlos F.T, Miguel A, Myriam G, Ivan A, Sara H, Ditmar B.K, Gonzalo Z , Jose T, Pilar I, Silvana T, Gabriel L, Walkyria B. S, Aldo N and Cimelio B (2018). Sustainable and Low Greenhouse Gas Emitting Rice Production in Latin America and the Caribbean: A Review on the Transition from Ideality to Reality; Sustainability 2018, 10, 671

[19] Nhemachena, C., and R. Hassan (2007). Micro-level Analysis of Farmers' Adaptation to Climate Change in Southern Africa. International Food Policy Research Institute (IFPRI) Discussion Paper No. 00714. Environment and Production Technology Division, IFPRI, Washington, D.C.

[20] Nigeria Population Commission (NPC) (2006). Nigeria Population Commission, Nigeria Federal Government Initiative of individual head count by gender. Spread, State by State, In :MOFINEWS; (accessed 28 February, 2016).Jan-Feb,2007, 6(3):Nigeria.

[21] Nigerian Meteorological Agency (NiMET) (2018). "Drought and Flood Monitoring in South East Bulletin". Retrived from www .nimet.gov.ng 25 October, 2018

[22] Nwaiwu, J.C (2015). Farmers' adoption of some arable crop soil conservation practices in Imo State; Unpublished P.hD Thesis, Submitted to the Department of Agricultural Economics, Extension and Rural Development, Imo State University, Owerri, Nigeria

[23] Ojo, O.T, A. A. Ogundeji, S. C. Babu and T. Alimi (2020). Estimating financing gaps in rice production in Southwestern Nigeria; 9:12 https://doi.org/10.1186/s40008-020-0190-y

[24] Yamano, T.; Arouna, A.; Labarta, R.A.; Huelgas, Z.M. (2016). Adoption and impacts of international rice research technologies. Glob. Food Secur. 8, 1-8.

[25] Zhang, C. L, Chao L, Jun Z, Aixing D, Kees J and Weijian Z (2019). Acclimation of methane emissions from rice paddy fields to straw addition; Sci $A d v 5$ (1), eaau9038.

[26] Onubuogu, G,C and N.S Esiobu (2020). Determinants of allocative (pricing) efficiency of cassava farms in Imo State, Nigeria; Journal of Agriculture and Food Sciences; Vol 17 No 2; https://www.ajol.info/index.php/jafs/article/view/194543 